\title{
IMPLIKASI YURIDIS PENGATURAN KEPUTUSAN TATA USAHA NEGARA FIKTIF POSITIF DAN FIKTIF NEGATIF
}

\author{
Makhtum Yandi Abrory \\ Magister Ilmu Hukum Universitas Islam Malang \\ Email : mahtum1993@gmail.com
}

\begin{abstract}
Abstrak
Jawaban yang diperoleh penulis dalam penelitian ini yaitu dengan adanya pengaturan di dalam UUPTUN yang berimplikasi permohonan tersebut ditolak dan di dalam UUAP permohonan tersebut diterima dianggap dikabulkan maka berimplikasi tidak adanya kepastian hukum, adanya perluasan makna KTUN, adanya dua hukum acara PTUN, kewenangan PTUN, dan berlakunya mengikatnya KTUN. harmonisasi ketentuan di dalam UUPTUN dan UUPTUN dilakukan dengan cara menggunakan teori preferensi, sehingga yang dapat diberlakukan untuk sebagai dasar pengaturan adalah ketentuan di dalam UUAP. Oleh sebab itu perlu dilakukan legislative refiew untuk merevisi UUPTUN.
\end{abstract}

Kata kunci: KTUN, permohonan, sikap diam

\begin{abstract}
The answers obtained by the authors in this study that with the arrangement in UUPTUN implicating the application is rejected and in the UUAP the request is accepted considered granted, it implies the absence of legal certainty, the extension of the meaning of KTUN, the existence of two law of the PTUN event, the authority of PTUN, and the enactment of binding it KTUN. harmonization of provisions in UUPTUN and UUPTUN is done by using the theory of preference, so that which can be applied for the basis of arrangement is provision in UUAP. Therefore, legislative refiew needed to revise the UUPTUN.
\end{abstract}

Keywords: KTUN, petition, silence

\section{PENDAHULUAN}

Gagasan negara hukum dewasa ini merupakan sebuah konsep yang telah diterima dalam kehidupan berbangsa dan bernegara. Termasuk Negara Republik Indonesia dalam Pasal 1 ayat (3) Undang- Undang Dasar Negara Republik Indonesia Tahun 1945 menyebutkan bahwa Negara Indonesia adalah Negara hukum. Konsekuensi dari negara hukum adalah segala aktivitas bernegara harus berdasarkan pada hukum, dan perlunya pembatasan kekuasaan terhadap penyelenggara Negara. Hal itu dimaksudkan untuk melindungi hak-hak individu warga Negara dari tindakan sewenang-wenang penguasa. ${ }^{1}$

\section{hlm.5}

${ }^{1}$ Ridwan HR. Hukum Administrasi Negara, Edisi Revisi, Jakarta. Rajawali Pers, 2014. 


\section{Hurnal Negara dan $\mathcal{X}$ eadilan \\ p-ISSN 2302-7010 e-ISSN 2721-9801}

Dalam penyelenggaraan negara peranan pemerintah sangatlah diperlukan terutama di dalam Negara hukum kesejahteraan welfarestate. Itu artinya pemerintah ikut berperan aktif dalam setiap pergaulan hidup kemasyarakatan. Oleh sebab itu pemerintah perlu melakukan tindakan-tindakan yang biasa disebut dengan tindakan pemerintah (bestuurshandeling). ${ }^{2}$ Dengan dianutnya konsep negara hukum, maka semua campur tangan pemerintah dalam kehidupan masyarakat tersebut diberikan bentuk hukum demi memberikan kepastian hukum kepada semua pihak. Sehingga menjadi hal yang mendasar terkait dengan kewenangan pemerintah dalam melakukan suatu tindakan yang berdasar atas hukum.

Tindakan pemerintah yang paling banyak digunakan dalam hal pelaksanaan tugas-tugas pemerintahan ini adalah dalam bentuk penetapan atau keputusan tata usaha negara (beschikking). ${ }^{3}$ Hal itu juga sebagaimana yang dikatakan H.D. van Wijk dan Willem Konijnenbelt, dimana beschikking merupakan keputusan pemerintahan yangmsejak dulu dijadikan instrumen yuridis pemerintahan yang utama. ${ }^{4}$ Hal ini dikarenakan Keputusan Tata Usaha Negara (KTUN) merupakan salah satu instrumen yuridis yang bersifat konkret dari tindakan pemerintah yang memiliki konsekuensi menimbulkan akibat-akibat hukum tertentu.

Dewasa ini masyarakat lebih bergantung kepada KTUN, karena semakin lama banyak urusan urusan masyarakat yang harus diikat dengan suatu persetujuan maupun izin. Sehingga tidak jarang permasalahan adminsitrasi negara yang makin banyak ditemui di Indonesia, yaitu dengan banyaknya gugatan yang dilakukan terhadap Keputusan Tata Usaha Negara. ${ }^{5}$ Konsep KTUN yang dimaksud UUPTUN dapat difahami tidak hanya penetapan yang dikeluarkan atas inisiatif pejabat TUN namun juga ada KTUN karena adanya suatu permohonan dari masyarakat. Hal ini menimbulkan sebuah kemungkinan yaitu adanya tindakan pasif yang difahami sebagai sikap diam pejabat administrasi terhadap suatu permohonan. Sehingga di dalam Pasal 3 ayat (3) UUPTUN memberikan pengaturan Badan atau pejabat pemerintahan (Tata Usaha Negara) yang tidak menetapakan KTUN yang dimohon sedangkan undang-undang tidak mengatur batas waktu maka batas waktu penetapan sebagaimana ditentukan oleh peraturan perlu maka badan atau pejabat maka setelah lewat jangka waktu empat bulan sejak diterimanya permohonan, Badan atau Pejabat Tata Usaha Negara yang bersangkutan dianggap telah mengeluarkan keputusan penolakan. ${ }^{6}$

Sejalan perkembangan arah tuntutan pelayanan publik, maka telah diundangkan Undang-Undang Nomor 30 tahun 2014 tentang Administrasi Pemerintahan. Undang-undang tersebut dapat dijadikan sebagai hukum materiil bidang hukum administrasi negara dan sebagai dasar hukum penyelenggaraan pemerintahan. mengingat UUPTUN sebagai hukum formil dalam setiap penegakan hukum administrasi Negara. Kehadiran Undang-undang No.30 Tahun

${ }^{2}$ Sadjijono, Bab-Bab Pokok Hukum Administrasi, Cet. II, Edisi II.Yogyakarta, , LaksBang, 2011. h. 84.

${ }^{3}$ S. Prajudi Atmosudirdjo, Hukum Administrasi Negara, Cet. X, Jakarta.Ghalia Indonesia, 1994 .hlm.94

${ }^{4}$ Ridwan HR., op.cit, hlm. 141

${ }^{5}$ S.Prajudi Atmosudirdjo,Op.Cit hlm.79

${ }^{6}$ Pasal 3 ayat (3) UUPTUN 


\section{$\mathcal{H}$ urnal Negara dan Keadilan \\ p-ISSN 2302-7010 e-ISSN 2721-9801}

2014 tentang Administrasi Pemerintahan telah membawa perubahan yang signifikan terhadap perkembangan administrasi negara. Salah satunya berkaitan dengan pelayanan yang membutuhkan bentuk surat keputusan yang sesuai dengan permohonan yang diinginkan oleh masyarakat seperti ijin, akta-akta, dan lain-lain.

Berbeda dengan UUPTUN, Undang-ndang Administrasi Pemerintahan menyebutkan didalam Pasal 53 ayat (2) dan (3) Undang-Undang Nomor30 Tahun 2014 tentang Adminitrasi Pemerintahan bahwa: jika ketentuan peraturan perundang-undangan tidak menentukan batas waktu kewajiban sebagaimana dimaksud pada ayat (1), maka Badan dan/atau Pejabat Pemerintahan wajib menetapkan dan/atau melakukan Keputusan dan/atau Tindakan dalam waktu paling lama 10 (sepuluh) hari kerja setelah permohonan diterima secara lengkap oleh Badan dan/atau Pejabat Pemerintahan. Sedangkan dalam ketentuan Pasal 53 ayat (3) UU Administrasi Pemerintahan menentukan bahwa: "Apabila dalam batas waktu sebagaimana dimaksud pada ayat (2), Badan dan/atau Pejabat Pemerintahan tidak menetapkan dan/atau melakukan Keputusan dan/atau Tindakan, maka permohonan tersebut dianggap dikabulkan secara hukum."

Dengan demikian keberadaan kententuan Pasal 3 ayat (3) UU PTUN dan ketentuan Pasal 53 ayat (2) dan (3) UU Administrasi Pemerintahan menunjukkan bahwa telah terjadi pertentangan norma atau norma yang konflik (conflict of norm, geschijld van normen) antara kedua undang-undang tersebut. Sehingga hal ini menujukan disharmonitas antara kedua undang-undang. Mengingat kedua undang-undang tersebut sama-sama merupakan hukum positif di Indonesia. Dengan adanya pertentangan norma tersebut menimbulkan ketidakpastian hukum dan keragu-raguan dalam penerapannya.

\section{METODE PENELITIAN}

Jenis penelitian dalam penelitian ini adalah yuridis normatif karena penelitian ini didasarkan atas pemikiran yang logis. Adapun penelitian hukum normatif mencakup penelitian terhadap sistematika hukum, penelitian terhadap taraf sinkronisasi hukum, penelitian sejarah hukum dan penelitian perbandingan hokum. ${ }^{7}$ Dalam penelitian normatif ini menggunakan pendekatan perundangundangan (statute approach) dan pendekatan analitis. ${ }^{8}$ Dalam penelitian ini metode pengumpulan bahan dilakukan dengan cara melakukan penelusuran literatur hukum dan literature lainnya yang didapat melalui studi kepustakaan maupun situs-situs online yaitu internet. Analisis bahan hukum mwerupakan upaya penelusuran dari bahan hukum yang telah diolah untuk mendapatkan kesimpulan. Analisis yang digunakan adalah dengan metode pengkajian deduksi deskriptif secara yuridis kualitatif.

\section{PEMBAHASAN}

KTUN merupakan bagian dari tindakan hukum pejabat administrasi negara (rechtshandeling). Sehingga pengaturannya perlu dipertimbangkan di dalam negara hukum. KTUN di Indonesia telah diatur sebelumnya di dalam pasal 1

\footnotetext{
${ }^{7}$ Soerjono Soekanto, Pengantar Penelitian Hukum, Jakarta, UI Press, 2000. hlm. 51

${ }^{8}$ Ibid.hlm.310
} 


\section{Zurnal Negara dan $\mathcal{X}$ eadilan \\ p-ISSN 2302-7010 e-ISSN 2721-9801}

angka 3 UUPTUN yang menyatakan bahwa: "Keputusan Tata Usaha Negara adalah suatu penetapan tertulis yang dikeluarkan oleh badan atau pejabat tata usaha negara yang berisi tindakan hukum tata usaha negara yang berdasarkan peraturan perundang-undangan yang berlaku, yang bersifat konkret, individual, dan final, yang menimbulkan akibat hukum bagi seseorang atau badan hukum perdata.

Dengan adanya pengertian tersebut maka dapat dimaknai bahwa KTUN merupakan tindakan aktif dari Pejabat TUN. Sehingga apabila seseorang atau badan hukum perdata yang merasa dirugikan atas dikeluarnya KTUN, maka mereka dapat melakukan gugatan TUN di PTUN sebagaimana yang diatur di didalam Peraturan Perundang-undangan.

Perlu diketahui bahwa untuk dikeluarkan suatu KTUN dapat berasal dari inisiatif pejabat TUN itu sendiri dan juga dapat disebabkan karena adanya suatu permohonan yang berasal dari seseorang atau badan hukum perdata untuk dikeluarkan suatu KTUN. Akibat dari permohonan tersebut, KTUN yang diterbitkan dapat berbentuk penolakan (negative) atau penerimaaan (positif). Namun pertanyaan yang muncul berikutnya yaitu bagaimana jika suatu permohonan tidak ditindak lanjuti oleh pejabat TUN?.

UUPTUN sendiri telah memperluas makna KTUN itu sendiri berdasarkan pasal 1 angka 3 UUPTUN. Berkaitan dengan kewajiban, dalam hukum administrasi negara, tidak dapat dipisahkan dengan kewenanagan. artinya pasal 3 ayat (1) UUPTUN menghendaki suatu tindakan dapat juga disebut sebagai KTUN apabila tindakan tersebut dilakukan oleh pejabat yang berwenang untuk mengeluarkan atas adanya suatu permohonan.

Apabila suatu peraturan perundang-undangan tidak menentukan batas waktu penetapannya untuk dikeluarkan, maka sejak lewat jangka waktu empat bulan sejak diterima permohonan, Pejabat TUN tersebut dianggap mengeluarkan keputusan penolakan. Dari penjelesan tersebut dapat difahami bahwa adanya ketentuan jangka waktu empat bulan dan bentuk keputusannya adalah ditolak. Pembuat undang-undang memberikan jangka waktu empat bulan adalah dalam rangka menjamin kepastian hukum. Pemohon tidak terus menunggu konfirmasi dari pejabat TUN. Terkait dengan bentuk keputusan ditolak, dapat dikatakan dengan adanya sikap diam tersebut tidak menimbulkan keadaan hukum baru. Artinya dengan ditolaknya suatu permohonan maka keadaan akan sama antara sebelum adanya permohonan maupun setelah adanya permohonan.

Sikap diam tersebut dapat dikatakan karena atas dasar kesengajaan maupun kelalaian dari pejabat TUN. Pejabat TUN bisa saja tidak melakukan tindak lanjut atas suatu permohonan karena syarat-syarat yang harus dipenuhi terhadap permohonan tersebut belum lengkap. Sehingga wajar apabila pejabat TUN tersebut tidak melakukan tindakan lanjutan atas suatu permohonan. Itu sebabnya didalam ketentuan Pasal 3 UUPTUN tersebut tidak mensyaratkan permohonan harus lengkap. Sehingga dalam aturan tindakan tersebut dianggap menolak.

Sebaliknya apabila suatu permohonan yang syarat-syaratnya telah terpenuhi, dengan adanya sikap diam tersebut maka akan berimplikasi pada kepentingan hukum pemohon. Dimana dengan adanya ketentuan "menolak" maka permohonan tersebut meskipun syarat-syarat terpenuhi, maka tidak akan dikabulkan. Sikap diam tersebut dapat berupa adanya kelalaian dari pejabat TUN yang berwenang. Hal ini menurut penulis tidak tepat apabila dikaitkan dengan konsep negara 


\section{Jurnal Negara dan Zeadilan \\ p-ISSN 2302-7010 e-ISSN 2721-9801}

hukum sendiri. Dimana negara dalam menjalankan fungsinya harus menjamin hak-hak pribadi manusia. ${ }^{9}$ terlebih konsep negara hukum modern lebih mengedepankan negara hukum (welfarestate). Sehingga fungsi negara dalam arti materiil adalah bertindak sebagai pelayan bagi masyarakat (public service). ${ }^{10}$

Disini pembuat undang-undang dalam politik hukumnya tidak menekankan alasan akibat sikap diam dari pejabat TUN. Namun Pembentuk undang-undang mengarahkan norma dalam pasal 3 UUPTUN diatas hanya untuk memperluas cakupan arti KTUN. Dimana KTUN tidak hanya sebatas apa yang disebut didalam pasal 1 angka 9 UUPTUN. Serta Pembentuk undang-undang ingin membentuk sebuah prinsip umum yang menyatakan bahwa "menolak mengeluarkan suatu keputusan disamakan sebagai suatu keputusan".

Ini berarti Pasal 3 ayat (3) Undang-Undang PTUN dapat disebut dengan keputusan tata usaha negara atas suatu permohonan yang batas waktu penetapannya tidak diatur oleh undang-undang yang diistilahkan sebagai fiktif negative. Karena memuat konteks tentang "fiktif" yang menunjukkan bahwa KTUN yang digugat sebenarnya tidak berwujud. Ia hanya merupakan sikap diam dari badan atau pejabat tata usaha negara yang kemudian dianggap disamakan dengan sebuah pengertian KTUN yang nyata tertulis. Sedangkan istilah "negatif" menunjukkan bahwa KTUN yang digugat dianggap berisi penolakan terhadap permohonan yang telah diajukan oleh orang atau badan hukum perdata.

Apabila badan atau pejabat tata usaha negara tidak mengeluarkan keputusan (diam saja), sedangkan hal itu menjadi kewajibannya, maka sikap diamnya tersebut disamakan dengan KTUN sehingga berimplikasi tindakan tersebut dapat digugat. Sebaliknya, Badan atau Pejabat TUN yang menerima suatu permohonan, tetapi permohonan itu bukan merupakan kewajibannya untuk menjawab, maka sikap diamnya tidaklah dapat dianggap sebagai KTUN yang fiktif-negatif. Dan oleh karena itu, dia tidak dapat digugat. ${ }^{11}$

Apabila seseorang merasa keberatan dengan Keputusan Fiktif negative, maka dapat mengajukan gugatan ke PTUN menurut Pasal 53 ayat (1) UUPTUN. Berkaitan dengan gugatan, penggugat harus mampu membuktikan bahwa telah terjadi adanya suatu permohonan kepada pejabat TUN yang berwenang. Dimana permohonan tersebut telah diterima oleh pejabat TUN tersebut. untuk mengetahui atau menentukan suatu permohonan tersebut diterima atau tidak tentu harus ada suatu bentuk surat tanda penerimaan yang menjelaskan bahwa permohonan tersebut telah diterima. Surat tanda penerimaan tersebut dapat dijadikan dasar untuk menghintung hari untuk menentukan lewat jangka waktu mengajukan gugatan di PTUN.

Berlakunya UUAP membawa perubahan besar dalam sistem peradilan tata usaha negara di Indonesia. termasuk di dalam konsep pengaturan KTUN yang berasal dari adanya suatu permohonan dari masyarakat. Termasuk juga pengaturan KTUN atas suatu permohonan yang batas waktu penetapannya tidak

\footnotetext{
hlm. 28

${ }^{9}$ Asmuni, Konsep Pelaksanaan Keputusan Tata Usaha Negara. Malang: Stara Pers. 2017.

${ }^{10}$ B. Hestu Cipto Handoyo, Hukum Tata Negara Indonesia "Menuju Konsolidasi Sistem Demokrasi, Jakarta : Universitas Atma Jaya, 2009, hal.20

${ }^{11}$ Zairin Harahap. Hukum Acara Peradilan Tata Usaha Negara. Jakarta: PT. Raja Grafindo Persada. 1997, hlm. 29
} 


\section{Hurnal Negara dan $\mathcal{X}$ eadilan \\ p-ISSN 2302-7010 e-ISSN 2721-9801}

diatur oleh peraturan perundang-undangan, diantaranya disebutkan dalam pasal 53 UUAP

Hal-hal yang perlu diperhatikan di dalam ketentuan tersebut yang pertama adalah pejabat pemerintahan wajib menetapkan suatu keputusan atau ketetapan atas adanya suatu permohonan. Sehingga apabila pejabat tersebut berwenang maka hal tersebut merupakan suatu kewajiban yang harus dilakukan oleh pejabat tun. Apabila kewajiban tersebut tidak dilakukan, maka tentu harus membawa akibat hukum terhadap tindakannya tersebut. Jangka waktu 10 hari kerja tersebut adalah paradigma baru yang diberlakukan di dalam UUAP adalah menuntut pejabat pemerintahan untuk bekerja lebih aktif.

Politik hukum dalam pemberlakuan ketentuan diatas untuk menjamin kepastian hukum bagi masyarakat dalam suatu permohonan. Serta adanya ketentuan demikian karena ditekankan dalam menjalankan pelayanan publik. Para birokrat dituntut untuk bertindak lebih aktif dan professional dalam melaksanakan tugasnya. Sehingga pemerintah perlu dibebankan sebuah tanggung jawab. Selain itu pemerintah sebagai pejabat administrasi di dalam mengeluarkan kebijakan (beleid) biasanya hanya berdasarkan interpretasi yang dipahami olehnya. Namun dengan adanya kebebasan bertindak pada pemerintah dalam menjalankan fungsi administrasi dapat saja terjadi perbuatan atau tindakan yang menyimpang dari peraturan hukum yang berlaku sehingga tendensinya dapat menimbulkan kerugian pada pihak administrabele. ${ }^{12}$

Penjelasan diatas sesuai dengan penjelasan dari Guntur Hamzah pada saat pembahasan UUAP yang mengemukakan bahwa adanya perubahan dari fiktif negative menjadi fiktif positif lebih dikarenakan untuk mendesak pemerintah agar dapat lebih cepat dalam memproses suatu permohonan sehingga masyarakat atau pihak yang mengajukan permohonan tersebut akan mendapatkan kepastian hasil keputusan lebih cepat dan tidak terbelit-belit. Hal ini tentunya sejalan dengan proses reformasi birokrasi, terutama dalam hal peningkatan pelayanan publik. ${ }^{13}$

Apabila pejabat pemerintahan tidak mengeluarkan KTUN dalam jangka waktu 10 hari kerja sejak permohonan diterima secara lengkap, maka permohonan tersebut dianggap dikabulkan secara hukum. Keputusan semacam ini dalam hukum administrasi dikenal dengan keputusan fiktif positif.

Ketenttuan fiktif positif diatas tidak semata-mata berlaku begitu saja. Namun harus memenuhi persyaratan yaitu permohonan tersebut harus lengkap. dimana pemohon harus mampu membuktikan bahwa permohonan tersebut memang benar-benar diterima oleh pejabat pemerintahan. Selain itu yang dimaksud pejabat pemerintahan adalah pejabat yang berwenang untuk melakukan tindakan berupa surat keputusan. Pada dasarnya ketentuan pasal 53 ayat (3) UUAP sangat berhubungan dengan apa yang disebutkan didalam pasal 52 ayat (1) UUAP.

Untuk mendapatkan Penerimaan keputusan berdasarkan fiktif positif masih diperlukan sebuah proses peradilan untuk memutusnya. Adanya pengaturan tersebut karena pembuat UU-AP sesungguhnya menyadari bahwa, meskipun dianggap telah dikabulkan, hak yang timbul dari Keputusan Tata Usaha Negara 1982 hlm. 74.

${ }^{12}$ Muchsan. Pengantar Hukum Administrasi Negara Indonesia. Yogyakarta: Liberty,

${ }^{13}$ Anotasi Undang-Undang No.30 Tahun 2014 tentang Administrasi Pemerintahan hlm. Hlm.201 


\section{$\mathcal{H}$ urnal Negara dan Keadilan \\ p-ISSN 2302-7010 e-ISSN 2721-9801}

yang bersifat fiktif positif masih berbentuk abstrak dan tidak dapat memberikan jaminan kepastian hukum secara praktik.

Dewasa ini Mahkmah Agung sebagai lembaga negara yang menjalankan fungsi kekuasaan kehakiman untuk mengatasi masalah tersebut telah mengundangkan Peraturan Mahkamh Agung No. 5 Tahun 2015 tentang pedoman beracara untuk memperoleh putusan atas penerimaan permohonan guna mendapatkan keputusan dan/atau tindakan badan atau pejabat pemerintahan. karena di dalam UUPTUN belum mengatur adanya hukum acara terkait dengan permohonan fiktif positif.

Jika ditinjau berdasarkan pembahasan awal, bahwa pengaturan mengenai keputusan tata usaha negara yang batas waktu penetapannya tidak diatur oleh peraturan perundang-undangan dimuat dalam dua aturan yang berbeda. Dimana hal itu diatur didalam pasal 3 ayat (3) UUPTUN dan pasal 53 ayat (3) UUAP yang konsep pengaturan keduannya tersebut sangat berbeda. Hal ini tentu membawa implikasi yuridis.

Pertama, berkaitan dengan makna KTUN itu sendiri. Dimana Pengertian KTUN sendiri menurut UUPTUN dan UUAP sebagai penetapan tertulis, maka menjadi diperluas tidak hanya sebagai penetapan tertulis. Sikap diam pejabat tata usaha negara atas adanya suatu permohonan juga dapat dikatakan sebagai KTUN. sehingga tindakan tersebut dapat digugat ke pengadilan. Namun yang membedakan antara UUPTUN dan UUAP adalah didalam UUAP sikap diam tersebut harus di mintakan permohonan ke pengadilan TUN untuk memerintahkan Pejabat TUN mengeluarkan surat penetapan permohonan dikabulkan.

Dengan dimaknainya sikap diam pejabat TUN atas adanya suatu permohonan yang batas waktu penetapannya tidak diatur oleh peraturan perundang-undangan sebagai suatu KTUN, maka dapat dikatakan itu sebagai bentuk tindakan hukum publik pemerintah bersegi satu (eenzijdig publiekrechttelijke handeling). Yaitu suatu tindakan dari alat-alat perlengkapan pemerintah dalam baik aktif maupun pasif tidak perlu mendapat persetujuan dari pihak lain yang berimplikasi harus melindungi hak-hak asasi manusia dalam penyelenggaraan negara hukum.

Kedua, dengan diaturnya fiktif positif di dalam UUAP telah membawa impliksasi yuridis terhadap berlaku dan mengikatnya suatu KTUN. Sebelum adanya konsep fiktif positif, maka dianutnya konsep fiktif negative.berlakunya konsep fiktif negative tentu setelah melalui jangka waktu yang ditetapkan didalam UUPTUN maka keputusan tersebut telah mempunyai kekuatan hukum mengikat. Namun dengan berlakunya konsep fiiktif positif di dalam UUAP tidak membuat sikap diam pejabat TUN yang dianggap sebagai keputusan TUN mempunyai kekuatan hukum mengikat. Namun dibutuhkan sebuah permohonan ke PTUN untuk menetapkan. Sehingga keputusan TUN dianggap mempunyai kekuatan hukum mengikat setelah adanya putusan dari PTUN tentang perkara fiktif positif.

Ketiga, dengan berlakunya pengaturan sebagaimana yang telah dijelaskan diatas dapat dilihat bahwa dengan keberadaan Peraturan Mahkamah Agung No. 5 tahun 2015 berimplikasi terhadap hukum acara yang termuat didalam UUPTUN. Sehingga dapat dikatan bahwa sistem peradilan Tata Usaha Negara memiliki dua hukum acara yang berbeda. Dimana hukum acara yang pertama diatur didalam UUPTUN dan yang kedua diatur didalam Peraturan Mahkamah Agung No. 5 Tahun 2015 yang khusus berkaitan dengan keputusan yang besifat fiktif positif. 


\section{Hurnal Negara dan $\mathcal{X}$ eadilan \\ p-ISSN 2302-7010 e-ISSN 2721-9801}

Keempat, dengan berlakunya dua hukum acara yang dimiliki dalam sistem peradilan tata usaha negara tentu akan membawa implikasi terkait dengan kewenangan PTUN. Dimana kewenangan PTUN dalam sistem peradilan di Indonesia yaitu bertugas dan berwenang memeriksa, memutus, dan menyelesaikan sengketa tata usaha negara. ${ }^{14}$ Dimana sengketa menurut nurnaningsih amiriani sendiri adalah suatu situasi dimana ada pihak yang merasa dirugikan oleh pihak lain, yang kemudian pihak tersebut menyampaikan ketidakpuasan ini kepada pihak kedua. ${ }^{15}$ Kewenangan tersebut juga diatur di dalam Undang-undang No.49 tahun 2009 tentang kekuasaan kehakiman yang menyebutkan bahwa PTUN berwenang menyelesaikan sengeteka Tata Usaha Negara berdasarkan UUPTUN. Dengan adanya Perma No. 5 Tahun 2015 pasal 53 ayat (4) UUAP telah memperluas kewenangan yaitu tidak hanya sebatas menyelesaikan sengeketa namun berwenang memeriksa suatu permohonan fiktif positif. Hal ini menurut penulis permohonan fiktif positif bukan merupakan sengketa, melainkan seseorang meminta legitimasi dari pengadilan sebagaimana ditentukan oleh Undang-Undang.

Kelima, dengan adanya dua pengaturan mengenai keputusan TUN fiktif, maka menimbulkan konflik hukum yang berimplikasi secara yuridis tidak terciptanya kepastian hukum dalam hukum administrasi di Indonesia. Mengingat di Indoensia masih secara konkuren memberlakukan pengaturan fiktif negative dan fiktif secara bersamaan. Sehingga diperlukanlah harmonisasi anatara ketentuan di dalam kedua undang-undang tersebut.

Dari penjelasan dari bab-bab terhadulu maka dewasa ini berkaitan dengan Pengaturan Keputusan Tata Usaha yang batas waktu penetapannya tidak diatur oleh Peraturan perundang-undangan telah terjadi dualisme pengaturan. yaitu ketentuan didalam UUPTUN dan UUAP. Hal itu dikarenakan didalam UUAP tidak ada ketentuan yang mencabut keberlakuan ketentuan-ketentuan didalam UUPTUN. Namun hanya memberikan perluasan pemaknaan atas lingkup KTUN sebagaimana dinyatakan dalam Pasal 87 UUAP sehingga menjadi pertanyaan selanjutnya: ketentuan mana yang akan digunakan dalam hal pemerintah tidak menerbitkan suatu keputusan atas permohonan yang diajukan oleh warganegaranya. Hal tersebut memberikan potensi dispute yang sekiranya dapat mengurangi angin segar bagi warga negara yang sebelumnya telah dihembuskan oleh UUAP.

Jika dikaitkan dengan teori tujuan hukum sendiri dimana hukum dapat dikatakan sebagai himpunan petunjuk hidup (perintah dan larangan) yang mengatur tata tertib dalam suatu masyarakat, dan seharusnya ditaati oleh seluruh anggota masyarakat yang bersangkutan. Oleh Karen itu ada hukum yang bersifat mengatur (fakultatif, aanvuilend recht) dan bersifat memaksa (imperative, $d$ wingend recht). Namun dalam fungsi pemaksaan, dalam tubuh hukum itu sendiri harus membersihkan dirinya dari adanya permasalahan-permasalahan. Termasuk erat kaitanya dengan konflik norma antara satu norma dengan norma lain.

\footnotetext{
${ }^{14}$ Pasal 47 Undang-Undang Nomor 51 Tahun 2009 tentang Perubahan Kedua atas Undang Undang Nomor 5 tahun 1986 tentang Peradilan Tata Usaha Negara

${ }^{15}$ Nurnaningsih Amriani. Mediasi Alternatif Penyelesaian Sengketa Perdata Di Pengadilan. Jakarta: PT. Raja Grafindo Persada, 2012 hlm.12
} 


\section{$\mathcal{H}$ urnal Negara dan Keadilan \\ p-ISSN 2302-7010 e-ISSN 2721-9801}

Mengingat hukum tidak hanya dipandang sebagai suatu norma yang berdiri sendiri, melainkan hukum dalam keberlakuannya merupakan suatu sistem dimana sangat berhubungan.

Untuk itu diperlukan harmonisasi norma hukum dan konsistensi hukum dalam upaya pengaturan makna diam Pejabat Pemerintahan, sehingga kepastian hukum masyarakat dalam upaya memperoleh pelayanan yang baik oleh dan dari Pejabat Pemerintahan dapat tercapai secara optimal. Mengingat sejak diundangkannya UUAP maka hubungan peraturan tersebut tidak dapat dipisahkan. Dimana UUPTUN sebagai hukum formil dalam rangka menegakkan hukum materiel yaitu UUAP.

Untuk menilai pertentangan suatu norma yang dapat diberlakukan, maka sinkronisasi tersebut sangat lah penting. Adapun sinkronisasi peraturan perundang-undangan antara UUPTUN dengan UUAP menurut Endang Sumiarni lebih condong untuk menggunakan kata harmonisasi. Karena harmonisasi digunakan untuk mengkaji kesesuaian antara peraturan perundang-undangan secara horisontal atau yang sederajat dalam sistematisasi hukum positif. ${ }^{16}$ yaitu UU PTUN dan UU AP. Harmonisasi antara kedua undang-undang tersebut dapat dianalisis dengan cara-cara penyelesaian konflik norma. Secara ilmu perundangundangan jika dianalisis berdasarkan teori yang menggunakan asas Lex specialis derogat legi generali yang berarti. penafsiran hukum yang menyatakan bahwa hukum yang bersifat khusus (lex specialis) mengesampingkan hukum yang bersifat umum (lex generalis).

Jika dianalisis berdasarkan teori ini maka keberadaan UUPTUN tidak secara primer yang lebih tepat memuat norma substantif. Karena pada dasarnya UUPTUN sebagai hukum formil dalam menegakkan hukum materiel yang dimuat didalam UUAP. Sehingga ketika UUAP mengatur secara khusus, maka hemat penulis bahwa norma dalam UUPTUN harus dikesampingkan. Maka dapat dikatakan bahwa berkaitan dengan Keputusan fiktif positif mempunyai kekuatan yang lebih memikat dari pada Keputusan Fiktif negative. Karena UUAP adalah undang-Undang yang secara khusus mengatur mengenai hukum materiel dalam administrasi pemerintahan.

Hal ini juga sama jika dihubungan dengan asas hukum Lex Posterior Derogat Legi Priori yaitu pada peraturan yang sederajat. Dimana peraturan yang paling baru melumpuhkan peraturan yang lama. Secara yuridis formil keberadaan UUPTUN telah lebih dulu menjadi hukum positif. Sedangkan UUAP lahir setalah UUPTUN sendiri mengalami beberapa perubahan. Dengan demikian apabila terjadi suatu pertentangan konflik norma maka UUPTUN di kesampingan dari pada ketentuan UUAP dalam hal ini keberlakuan Keputusan yang bersifat fiktif positif. Keberlakuan keputusan fiktif positif ini juga telah dibuktikan dengan adanya Peraturan Mahkamah Agung No.5 tahun 2015.

Selain itu harmonisasi juga dapat dilakukan dengan cara pembatalan (invalidation). Meskipun secara praktik memang keberadaan fiktif negative telah ditinggalkan. Namun jika dianilisis sebagai konsekuensi logis dari negara hukum dalam penyelenggaraanya harus menciptakan kepastian hukum. Yaitu melalui lembaga dan upaya yang tersedia. Dimana upaya tersebut dapat melalui Uji materiel di Mahkamah Konstitusi maupun pembatalan suatu norma melalui

${ }^{16}$ Endang Sumiarni, Metodologi Penelitian Hukum Dan Statistik, Yogyakarta. hal. 5 


\section{Zurnal Negara dan $\mathcal{X}$ eadilan \\ p-ISSN 2302-7010 e-ISSN 2721-9801}

Legislatif review yaitu melalui jalan parlemen. ${ }^{17}$ Harmonisasi/sinkronisasi hukum ini sangatlah penting mengingat pula telah ditegaskan Program Pembangunan Nasional (PROPENAS), bahwa "sasaran program ini adalah terciptanya harmonisasi peraturan perundang-undangan yang sesuai dengan aspirasi masyarakat dan kebutuhan pembangunan". Sinkronisasi vertikal dan horisontal menelaah sampai sejauh mana hukum positif tertulis yang berlaku bagi suatu bidang yang sama itu sinkron. ${ }^{18}$

\section{PENUTUP}

Dengan diaturnya keputusan tata usaha negara yang batas waktu penetapannya tidak diatur oleh Undang-Undang di dalam pasal 53 ayat (3) UUAP yang menganut prinsip fiktif positif mengubah pasal 3 UUPTUN yang menganut prinsip fiktif negative sehingga membawa implikasi yuridis yaitu, Perluasan makna KTUN, Berlaku mengikatnya suatu KTUN, Sistem hukum acara peradilan Administrasi di dalam UUPTUN, Kewenangan PTUN dan Tidak terciptanya kepastian hukum. Adanya pengaturan yang berbeda di dalam norma UUPTUN dan UUAP menimbulkan adanya suatu konflik norma. Sehingga perlu dilakukan harmonisasi. Harmonisasi antara kedua Undang-Undang tersebut yaitu dengan menggunakan asas Lex specialis derogat legi generali yang berarti. Sehingga yang dapat diberlakukan adalah didalam UUAP. Karena secara prinsip UUAP sebagai hukum materiel didalam Hukum Administrasi negara Indonesia.

\section{Buku}

\section{DAFTAR PUSTAKA}

Amriani, Nurnaningsih.2012. Mediasi Alternatif Penyelesaian Sengketa Perdata Di Pengadilan. Jakarta: PT. Raja Grafindo Persada

Asmuni. 2017. Konsep Pelaksanaan Keputusan Tata Usaha Negara. Malang:Stara Pers

Atmosudirdjo,S. Prajudi, 1994. Hukum Administrasi Negara, Cet. X. Jakarta: Ghalia Indonesia,

Goesniadhie, Kusnu. 2006. Harmonisasi Hukum Dalam Perspektif Perundangundangan, Surabaya,: PT. Temprina Media Grafika

Handoyo, B. Hestu Cipto. 2009. Hukum Tata Negara Indonesia "Menuju Konsolidasi Sistem Demokrasi”, Jakarta :Universitas Atma Jaya

Harahap, Zairin.1997. Hukum Acara Peradilan Tata Usaha Negara. Jakarta: PT. Raja Grafindo Persada

Muchsan. 1982. Pengantar Hukum Administrasi Negara Indonesia. Yogyakarta: Liberty

Muh. Bakri. 2011. Pengantar Hukum Indonesia; Perbidangan dan asas-asas Hukum Jilid 1. Malang: UB Pers.

Ridwan HR.2014, Hukum Administrasi Negara, Edisi Revisi. Jakarta: Rajawali Pers

${ }^{17}$ Muh. Bakri. Pengantar Ilmu Hukum, Perbidangan dan asas-asas Hukum jilid 1.Malang. UB Pers. 2012, hal. 89

${ }^{18}$ Kusnu Goesniadhie, Harmonisasi Hukum Dalam Perspektif Perundang-undangan, Surabaya,: PT. Temprina Media Grafika 2006, hal. 23-24 


\section{Hurnal Negara dan $\mathcal{X}$ eadilan \\ p-ISSN 2302-7010 e-ISSN 2721-9801}

Sadjijono, 2011, Bab-Bab Pokok Hukum Administrasi, Cet. II, Edisi II. Yogyakarta: LaksBang

Soekanto, Soerjono.2000.Pengantar Penelitian Hukum, Jakarta: UI Press

Anotasi Undang-Undang No.30 Tahun 2014 tentang Administrasi Pemerintahan

\section{Peraturan Perundang-undangan}

Undang-Undang Dasar Negara Republik Indonesia Tahun 1945

Undang-Undang Republik Indonesia Nomor 5 Tahun 1986 tentang Peradilan Tata Usaha Negara

Undang-Undang Republik Indonesia Nomor 9 Tahun 2004 tentang Perubahan Atas Undang-Undang Republik Indonesia Nomor 5 Tahun 1986 Tentang Peradilan Tata Usaha Negara

Undang-Undang Republik Indonesia Nomor 51 Tahun 2009 tentang Perubahan Kedua Atas Undang-Undang Republik Indonesia Nomor 5 Tahun 1986 Tentang Peradilan Tata Usaha Negara

Undang-Undang Republik Indonesia Nomor 12 Tahun 2011 tentang Pembentukan Peraturan Perundang-undangan

Undang-Undang Republik Indonesia Nomor 30 Tahun 2014 tentang Administrasi Pemerintahan

Peraturan Mahkamah Agung Nomor 5 Tahun 2015 tentang Pedoman Beracara Untuk Memperoleh Putusan Atas Penerimaan Permohonan Guna Mendapat Keputusan Dan/Atau Tindakan Badan Atau Pejabat Pemerintahan

\section{Jurnal}

Budi Amin. 2017. Keputusan Fiktif Negatif dan Fiktif Positif Dalam Peningkatan Kualitas Pelayan Publik. Tanjung Pura: Jurnal Hukum . Volume 1, No.1 Januari 2017

Enrico Simanjutak. 2017. Perkara Fiktif Positif. Jakarta Pusat : Jurnal Hukum dan Peradilan Volume 6 No.3 November 2017

Maftuh Efendi. Peradilan Tata Usaha Negara Indonesia sutau pemikiran ke arah perluasan kompetensi pasca amandemen kedua Undang-Undang PTUN, Jurnal Hukum dan Peradilan Volume no. 3 tanggal 1 maret 2014

Salmon, Hendrik. 2010. "Eksistensi Peradilan Tata Usaha Negara (PTUN) Dalam Mewujudkan Suatu Pemerintahan Yang Baik" dalam H. Salmon: Jurnal Sasi Vol. 16 No. 4. 2010 